\title{
Comparative studies on the physicochemical and microbiological characteristics of different animal milk collected from the farms of Khartoum State, Sudan
}

\author{
Sabah Ibrahim Omer Ibrahim', Amir Mahgoub Awadelkareem², Syed Amir Ashraf* and \\ Murwan Khalid Sabahelkhier' \\ ${ }^{1}$ Department of Biochemistry and Molecular Biology, Faculty of Science and Technology, Al-Neelain \\ University, Sudan \\ ${ }^{2}$ Department of Clinical Nutrition, College of Applied Medical Sciences, University of Hail, Hail, Saudi Arabia
}

\begin{abstract}
Milk is considered as one of the finest natural foods containing all the essential nutrients such as lactose, fat, protein, minerals and vitamins in balanced ratio rather than the other foods. The present study was aimed to compare the physicochemical and microbiological qualities of cow, camel and goat milk farmed in Khartoum states. Milk samples were collected from the villages of Khartoum, Sudan and analyzed for nutritional and mineral variations. Our proximate analysis showed that, there was no significant difference ( $p$ > 0.05) in total solid content, moisture and fat content of cow, camel and goat milk. However, we found significant differences ( $p>0.05$ ) in cow, camel and goat milk for protein content, ash content, total acidity content and $\mathrm{pH}$. In addition to that, mineral analysis of entire samples revealed that level of potassium was highest followed by calcium and phosphorus. However, level of magnesium and zinc was found to be lowest in concentration. Microbiological investigation showed that, total viable count in cow, camel and goat was $3.5 \times 10^{3}, 7.5 \times 10^{3}$ and $4.5 \times 10^{3}$, respectively. Moreover, total coliform count was found to be 9, 7 and 6 in cow, camel and goat respectively count indicates possible poor hygienic practices at farm level. In addition to that, Yeast and Mold, Staphylococcus aureus, Escherichia coli and Salmonella was not detected in the samples. This work provides updated information on the current physicochemical and microbiological characteristics of cow, camel and goat milk collected from the farms of Khartoum, Sudan. This can be of great importance in the fields of dairy, food technology and food analysis.
\end{abstract}

KEY WORDS: MILK, PHYSICOCHEMCIAL ANALYSIS, MINERAL ANALYSIS, SUDAN

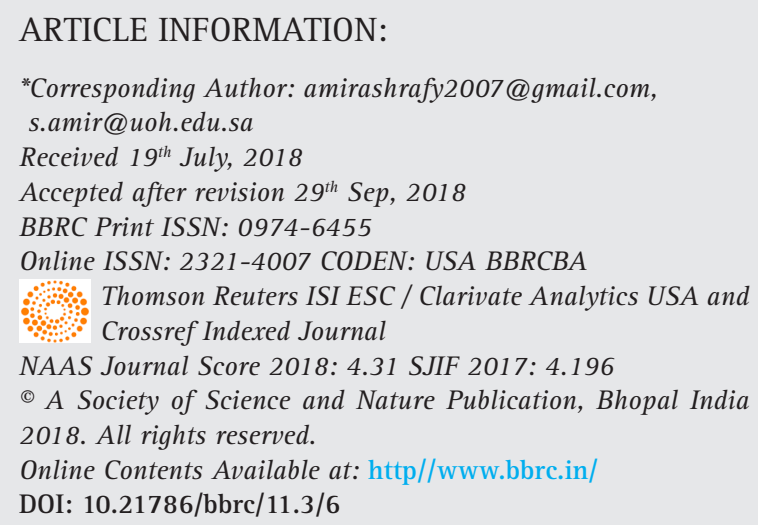




\section{INTRODUCTION}

Milk is one of the utmost important nutritious foods consumed throughout the world. It has been considered as key sources of all basic nutrients required for mammals including human beings. Milk is a complex colloidal dispersion containing fat globules, casein micelles and proteins in an aqueous solution of lactose, minerals and a few other minor compounds. Moreover, major chemical composition of milk has been reported in the form of water, carbohydrate, fat, protein, organic acids, enzymes and vitamins. Though, its physical and chemical properties depend on intrinsic compositional and structural factors, extrinsic factors such as temperature, diet and type of breed as well as post-milking treatments. In addition to that, milk from several animals such as cow, camel and goat etc. are used for various nutritional purposes such as feeding to young ones or used for dairy preparation such as milk cream, butter, yogurt, ghee, sour milk, etc., (Imran et al., 2008, Sood et al., 2016).

The health benefits of milk and other dairy products are known to humanity since ancient times and could be attributed due to naturally occurring active compounds that are existing in milk. Milk facilitates postnatal adaptation of baby through digestive maturation simultaneously by providing the bioactive components and nutrients. It supports lymphoid tissues development and in the establishment of symbiotic micro flora. The importance, potency and the quantity of milk bioactive compounds are possibly more than old consideration. They comprise certain specific organic acids, vitamin A, B12, D, riboflavin calcium, carbohydrates, phosphorous, selenium, magnesium, zinc, proteins, bioactive peptides and oligosaccharides (Ahmad et al., 2011; Homayouni et al., 2012, Gasmalla et al., 2017).

According to the Ministry of Livestock of Sudan (North African Country), an estimated 4.8 million ton of milk per year is produced of which $50 \%$ is used for direct human consumption and the remaining for bakeries and for feeding young stock. The average consumption is 6.5 million liters per day, which equals 0.18 liter (one cup of milk)/capita per day or 66 liter per year. Most of this milk is consumed directly without processing. Moreover, previous study shows major concerns for cow milk only, which represent $84 \%$ of the milk consumed around the world and to a lesser extent to other animal likewise camel and goat milk despite of their high nutritional importance (Dairy Quick Scan Sudan, 2016, Mayilathal et al., 2017).

Camel milk has been considered as an important source of proteins for the people living in the arid lands of the world. Its medicinal properties, has been widely exploited for human health. Camel milk is considered to possess anti-cancer, hypo-allergic and anti-diabetic properties. A high content in unsaturated fatty acids contributes to its overall dietary quality (Konuspayeva et al., 2008). On the other hand, goat is considered as the poor man's cow due to its great contribution to the health and nutrition of the landless and rural people. Consumption of goat milk should be enhanced because of its therapeutic properties and nutrition value (Mayilathal et al., 2017).

Goat was one of the first animals to be domesticated and it remained a popular animal serving the needs of human beings all over the world. Goat milk is one of the milk sources that was characterized as an economical, nutritional and medical importance, especially for children who suffer allergy from the cow milk. In addition to that, goat milk has high importance as a source of nutrition for poor communities (Warsama et al., 2015). Goat milk has high biological value and nutritional qualities due to its higher digestibility and its dietary characteristics with smaller diameter fat globules. It presents a chemical composition composed of proteins of high biological value and essential fatty acids, besides its mineral and vitamin content (Nascimento et al., 2017).

Based upon the nutritional facts and importance of animal milk such as cow, camel and goat their quality needs further exploration and updated information. The present study was carried out to evaluate and compare the physicochemical and microbiological properties of cow, camel and goat milk collected from the farms of Khartoum State, Sudan.

\section{MATERIAL AND METHODS}

\section{Collection of sample:}

A total of 9 fresh milk samples were collected during the month July-September 2017 from the individual animals (cow, camel and goat) by using hand milking and milk samples collected in separate sterilized containers used for sample collection. Then the collected samples were immediately transferred to an ice-box and transported to the laboratory for further chemical and microbiological study.

\section{Proximate Analysis:}

Total solid, moisture content, Lactose content and fat was measured as per method mentioned (El-Hag et al., 2013; Ashraf et al., 2016). Total protein was measured according to Kejldahl method using factor 6.38 (Bashir et al., 2015). pH, titratable acidity and ash was measured according to AOAC (2006) methods.

\section{Microbiological Analysis:}

Microbiological quality (Total viable count, yeast and mold, Staphylococcus aureus, coliform, Salmonella and E. coli) of the products were investigated by ISO (International Organization for Standardization) methods ISO: 
4833-2003, ISO: 21527-(2)2008, ISO: 6888-(1) 1999, ISO: 4832-2006, ISO: 6579-2004 and ISO: 6888-(1) 1999 respectively.

Determination of Milk Minerals : 2 gram milk sample and $10 \mathrm{ml}$ of $20 \%$ Nitric acid $\left(\mathrm{HNO}_{3}\right)$ were added to crucible. The mixture was initially heated at $70-85^{\circ} \mathrm{C}$ for 2 hours and later on placed into muffle furnace for another 3 hours. In addition to that, after completion of sample digestion the content of crucible was filtered using Nalgene filter (Thermo scientific) unit. The filtrate was collected in $100 \mathrm{ml}$ volumetric flask and allowed to cool. After cooling the volume was made up to 100 $\mathrm{ml}$ using deionized water and analyzed with ICP-MS (Inductive Coupled Plasma-Mass Spectrometry). For the sample preparation all the glassware was washed with deionized water and rinsed three times with 20\% nitric acid. Milk minerals were determined for calcium, phos- phorous, sodium, potassium, magnesium, zinc, iodine and cobalt (Alghamdi et al., 2018).

\section{Statistical Analysis:}

All the experiments were carried out in triplicates. The data were analyzed statistically with SPSS-17 statistical software (SPSS Inc., Chicago, IL, USA). Mean was statistically compared by student t test at $\mathrm{P}<0.05 \%$ level.

\section{RESULTS AND DISCUSSION}

Variations in the composition of cow, camel and goat milk collected from the farms of Khartoum state, Sudan. Physicochemical investigations were presented in table 1 . Moreover, mineral analysis showed a significant variation as depicted in table 2 . In addition to that, table 3 represents microbiological analysis.

\begin{tabular}{|c|c|c|c|}
\hline Parameters Sample & Cow & Camel & Goat \\
\hline Moisture content (\%) & $86.34 \pm 0.0^{\mathrm{a}}$ & $87.28 \pm 0.09^{a}$ & $87.71 \pm 0.07^{\mathrm{a}}$ \\
\hline Fat content (\%) & $3.63 \pm 0.01^{\mathrm{b}}$ & $4.3 \pm 0.01^{\mathrm{a}}$ & $3.90 \pm 0.12^{\mathrm{b}}$ \\
\hline Protein content (\%) & $3.42 \pm 0.10^{\mathrm{b}}$ & $3.83 \pm 0.15^{\mathrm{a}}$ & $4.81 \pm 0.12^{\mathrm{a}}$ \\
\hline Ash content (\%) & $0.813 \pm 0.06^{a}$ & $0.653 \pm 0.05^{\mathrm{b}}$ & $0.899 \pm 0.34^{\mathrm{a}}$ \\
\hline T.S.S (\%) & $15.0 \pm 0.05^{\mathrm{a}}$ & $15.28 \pm 0.01^{\mathrm{a}}$ & $14.66 \pm 0.057^{\mathrm{a}}$ \\
\hline $\mathrm{pH}$ & $6.42 \pm 0.01^{b}$ & $6.32 \pm 0.05^{c}$ & $6.47 \pm 0.05^{\mathrm{a}}$ \\
\hline Acidity (\%) & $0.230 \pm 0.06^{c}$ & $0.183 \pm 0.08^{b}$ & $0.153 \pm 0.03^{\mathrm{a}}$ \\
\hline Lactose (\%) & $3.19 \pm 0.01^{b}$ & $4.04 \pm 0.05^{\mathrm{a}}$ & $3.79 \pm 0.7^{c}$ \\
\hline
\end{tabular}

\begin{tabular}{|c|c|c|c|}
\hline Parameters $\quad$ Sample & Cow & Camel & Goat \\
\hline Calcium (mg/100 g) & $119.90 \pm 0.69$ & $119.27 \pm 3.43$ & $127 \pm 3.42$ \\
\hline Phosphorus (mg/100 g) & $95.03 \pm 0.72$ & $83.58 \pm 7.64$ & $66.36 \pm 9.91$ \\
\hline Magnesium (mg/100 g) & $13.42 \pm 0.24$ & $12.43 \pm 0.94$ & $11.86 \pm 1.28$ \\
\hline Sodium (mg/100 g) & $49.67 \pm 0.70$ & $68.58 \pm 3.52$ & $41.91 \pm 7.02$ \\
\hline Potassium (mg/100 g) & $147.02 \pm 1.55$ & $160.50 \pm 9.23$ & $133.57 \pm 10.42$ \\
\hline Zinc (mg/100 g) & $0.38 \pm 0.00$ & $0.519 \pm 0.035$ & $0.326 \pm 0.030$ \\
\hline Cobalt (mg/100 g) & $0.0599 \pm 0.007$ & $0.0638 \pm 0.0069$ & $0.0559 \pm 0.0084$ \\
\hline Iodine (mg/100 g) & $0.0336 \pm 0.004$ & $0.0357 \pm 0.0067$ & $0.0317 \pm 0.0049$ \\
\hline
\end{tabular}

\begin{tabular}{|l|l|l|l|}
\hline \multicolumn{2}{l|}{ Table 3. Microbiological analysis of cow, camel and goat milk } \\
\hline \multicolumn{1}{|c|}{ Sample } & Cow & Camel & Goat \\
\hline Parameters & & & \\
\hline Total viable count $\left(\mathrm{CFU} \mathrm{ml}{ }^{-1}\right)$ & $3.5 \times 103$ & $7.5 \times 103$ & $4.5 \times 103$ \\
\hline Yeast and Mold (CFU ml-1) & ND & ND & ND \\
\hline Staphylococcus aureus (CFU ml-1) & ND & ND & ND \\
\hline Total Coliforms (CFU ml-1) & 9 & 7 & 6 \\
\hline E. Coli (CFU ml $\left.{ }^{-1}\right)$ & ND & ND & ND \\
\hline Salmonella $25 \mathrm{ml}^{-1}$ & ND & ND & ND \\
\hline
\end{tabular}


Total solids and Moisture content: Our results showed that, the total solid content for cows, camels and goats milk in the present study were $15.0 \pm 0.05 \mathrm{a} \%, 15.28 \pm 0.01 \mathrm{a}$ and $14.66 \pm 0.057 \mathrm{a} \%$, respectively. The statistical analysis of the data showed non-significant differences ( $p>0.0$ 5) between cows, camels and goats milk. However, moisture analysis showed that, cow, camel and goat milk in the present study were $86.34 \pm 0.0 \mathrm{a}, 87.28 \pm 0.09$ a and $87.71 \pm 0.07$ a respectively as shown in table 1 . The statistical analysis of the data showed no significant difference $(p \leq 0.05)$ between three species and it was similar between them. Ealier reports reveal that, the total solid content in these milk was slightly lower than the observed results (Konuspayeva et al., 2008; Elsheikh et al., 2016 ).

Lactose content: The lactose content of cow, camel and goat milk in the present study were found to be $3.19 \pm 0.01 \%, 4.04 \pm 0.05 \%, 3.79 \pm 0.7 \%$, respectively as shown in Table 1. The lactose content of cows, camels and goats milk in the present study revealed that there was significant difference ( $\mathrm{p} \leq 0.05$ ) between cows, camels and goats milk. The lactose of camels milk in the present study was found to be similar to the previous reports (Konuspayeva et al., 2008). Moreover, lactose content in goat milk was not significant with the pervious study ie; $5.0 \pm 0.04 \%$ (Warsama et al., 2015).

Fat: The content of fat in cow, camel and goat milk in the present studies were $3.63 \pm 0.01 \%, 4.3 \pm 0.01 \%$ and $3.9 \pm 0.12 \%$ respectively as shown in table 1 . The statistical analysis showed, no significant difference ( $p>$ 0.05 ) between cow , camel and goat milk. The milk fat of camels support the findings determined by Shuiep et al., 2014. However, fat content in cow milk was similar to previous study ie; 3.70\% (Mourad et al., 2014). Moreover, the fat percentage in different milk samples could be due to genetic and environmental factors.

Protein: The content of the milk protein for cows, camels and goats were found to be $3.42 \pm 0.10 \mathrm{~b}, 3.83 \pm 0.15 \mathrm{a}$, $4.81 \pm 0.12$ a respectively as shown in Table 1 . The statistical analysis of the data showed significant difference ( $p>0.05$ ) between cows, camels and goats milk. This results was in accordance with the previous study (Mourad et al., 2014).

$\mathrm{pH}$ and Acidity: Table 1 shows that, the results of $\mathrm{pH}$ for cows, camels and goats milk in the present study were $6.42 \pm 0.01,6.32 \pm 0.05$ and $6.47 \pm 0.05$, respectively. In addition to that, acidity for cows, camels and goats milk were found to be $0.230 \pm 0.06 \%, 0.183 \pm 0.08 \%$ and $0.153 \pm 0$. o3\% respectively. The content of the $\mathrm{pH}$ and Acidity of cows, camels and goats milk in the present study the data revealed that there was significant difference $(p \leq 0.05)$ between cows, camels and goats milk. Our results were in accordance with the previous study (Fahmid et al.2016).
Ash: Our results shows that, cow, camels and goats milk had $0.813 \pm 0.0 \%, 0.653 \pm 0.05 \%$ and $0.899 \pm 0.034 \%$ of ash respectively as shown in Table 1 . The statistical analysis of the data showed significant difference $(p \leq 0.05)$ between camel from other species. The content of milk ash of camels in present study was similar to the previous study (Mourad et al., 2014).

\section{MINERAL ANALYSIS}

The results of calcium (Ca), Phosphorus (P), Magnesium (M), Sodium (Na), Potassium (K), Zinc (Zn), Cobalt (Co) and Iodine (I) for cow, camel and goat milk were presented in table 2 . The data indicated that there was highly significant difference $(p \leq 0.001)$ between goats with cow and camel milk. Goat milk had higher amount of calcium level than camel milk. The variation of Ca concentration in milk could be due to species, absorption and availability of Ca to the animal, environmental factors. Moreover, results of phosphorus showed a significant difference at ( $p \leq 0.05)$ between cows and other two species . No significant difference between camels and goats. The level of P in camel milk in present study was higher than values reported (Zamberlin et al., 2012). However, result of magnesium shows that, there was a significant difference ( $p \leq 0.05$ ) between $\mathrm{Mg}$ level of cows, camels and goats milk. The camel milk exhibited higher Mg level than goat milk. The level of $\mathrm{Mg}$ in camel milk in the present study was similar for the value demonstrated by (Konuspayeva, et al., 2009). Similarly, results of sodium and potassium showed highly significant different at ( $p$ $\leq 0.01$ ) in $\mathrm{Na}$ concentration between cows, camels and goats but no significant difference $(p>0.05)$ in $K$ concentration. The results of potassium, in the current study showed that there was no significant difference among the cows, camel and goats milk. The levels of micro minerals of cow milk in present study were $\mathrm{Zn} 0.38 \pm 0.00$, Co $0.0599 \pm 0.007$ and I $0.0336 \pm 0.004$, camels milk $\mathrm{Zn}$ $0.516 \pm 0.035$, Co $0.0638 \pm 0.0070$, and I $0.035 \pm 0.0072$ $\mathrm{mg} / 100 \mathrm{ml}$. Where, as the levels of micro minerals of goats milk $\mathrm{Zn} 0.326 \pm 0.030$, Co $0.0559 \pm 0.00837$, and I $0.035 \pm 0.0072$. The data revealed that, there was no significant difference ( $p>0.05$ ) between camels and goats milk in $\mathrm{Zn}$, Co and I concentrations.

\section{MICROBIOLOGICAL ANALYSIS}

The microbiological analysis results of cow, camel and goat milk were presented in table 3. Our data shows that, Salmonella spp were not detected in the milks. However, the number of total viable count in cow, camel and goat milk were found to be $3.5 \times 10^{3}, 7.5 \times 10^{3}, 4.5 \times 10^{3} \mathrm{CFU}$ $\mathrm{ml}^{-1}$, respectively. Moreover, total coliform count was found to be 9, 7 and 6 in cow, camel and goat respectively count indicates possible poor hygienic practices at 
farm level. In addition to that, Yeast and Mold, Staphylococcus aureus, E. Coli and Salmonella was not detected in the samples.

\section{CONCLUSION}

Milk is an essential product for human consumption as it is a complete food supplement in various parts of the world. Milk can be obtained from different animal species, such as goats, cows and camels. Our study focuses on the nutritional and microbiological characterization of cow, camel and goat milk. We found that, cow, camel and goat milk contained similar percentages of protein implying that any of them can adequately serve as a nutritional source of protein for human consumption. However, lactose and fat percentage had significant variation. In addition to that, the level of potassium was highest among the entire mineral tested. Detection of coliform and total viable count indicates poor hygienic conditions during the milking process by farmers. Furthermore, intensive studies should be carried out to investigate the vitamin and other micro nutrients present in milk. This work provides updated information on the physicochemical and microbiological characteristics of cow, camel and goat milk collected from the farms of Khartoum, Sudan. This can be of great importance in the fields of dairy, food technology and food analysis.

\section{ACKNOWLEDGEMENTS}

We are thankful to the Department of Biochemistry and Molecular Biology, Faculty of Science and Technology, Al-Neelain University, Sudan and Department of Clinical Nutrition, CAMS, University of Hail Hail KSA to carry out present study.

\section{CONFLICT OF INTEREST}

The authors do not have any conflict of interest.

\section{REFERENCES}

AOAC (Association of Official Analytical Chemists) (2006). Official Methods of Analysis, 18th edn. (Gaithersburg, S. edn). AOAC Press, Washington DC., USA.

Alghamdi, A.A., Awadelkarem, A. M., Hossain, A.B.M. S., Ibrahim, N.A., Fawzi, M., Ashraf, S.A. (2018). Nutritional assessment of different date fruits (Phoenix dactylifera L.) varieties cultivated in Hail province, Saudi Arabia. Bioscience Biotechnology Research Communication 11(2): 263-269.

Ahmad, M. F., Ashraf, S.A., Ahmad, F. A., Ansari, J. A., and Siddiquee, M. R.A. (2011). Nutraceutical market and its regulation. American Journal of Food Technology. 6: 342-347. 10.3923/ajft.2011.342.347
Bashir, A., Ashraf, S.A., Khan M. A., and Azad, Z.R.A.A. (2015). Development and compositional analysis of protein enriched soybean-pea-wheat flour blended cookies. Asian Journal of Clinical Nutrition. 7: 76-83.

Ashraf, S.A., Khan, S., Khan, M.A. and Azad, Z.R.A.A. (2016). Optimization of fat extraction technique in khorasan wheat using different solvent system. International Journal of Biosciences. 8(4): 36-42.

Dairy Quick Scan Sudan. The Friesian dairy development company, The Netherlands 2016.

El-Hag, F.M., Ahamed M.M.M., Mahmoud K.E.H., Khair, M.A.M., Elbushra, O.E., Ahamed, T.K. (2013). Assessment of rural and experimental dairy products under dryland farming in Sudan. African Journal of Agricultural Research. 8(47)5967-5977.

Elsheikh, N.A. H., Rahamtalla, S.A. and Abdalla, M.O. M. (2016). Chemical composition of raw milk produced and distributed in Khartoum State, Sudan. Asian Journal of Agriculture and Food Sciences. 03(01):34-39.

Fahmid, S., Sajjad, A., Khan, M., Jamil, N. and Ali J. (2016). Determination of chemical composition of milk marketed in Quetta, Pakistan. International Journal of Advanced Research in Biological Sciences. 3(5), 98-103.

Gasmalla, M. A. A., Tessema, H.A., Salaheldin, A., Alahmad, K., Hassanin, H. A.M., and Aboshora, W. (2017). Health benefits of milk and functional dairy products. MOJ Food Processing \& Technology. 4(4):108-111.

Homayouni A., Azizi A., Javadi M., Mahdipour, S. and Ejtahed, H. (2012). Factors influencing probiotic survival in ice cream: A review. International Journal of Dairy Sciences. 7: 1-10.

Imran, M., Khan, H., Hassan, S. S., and Khan, R. (2008). Physicochemical characteristics of various milk samples available in Pakistan. Journal of Zhejiang University SCIENCE B., (9)7: 546-551.

ISO (International Organization for Standardization) methods.

Konuspayeva, G. Faye, B., Loiseau, G. (2009). The composition of camel milk: A meta-analysis of the literature data. Journal of Food Composition and Analysis. 22: 95-101.

Mayilathal K., Thirumathal K., Thamizhselvi N., and Yasotha D. (2017). Comparative study on the chemical parameters of milk samples collected from cow, buffalo and goat at Dindigul district, Tamilnadu, India. International Journal of Recent Scientific Research .8(4):16612-16614.

McCarthy 0.J., Singh H. (2009) Physico-chemical Properties of Milk. In: McSweeney P., Fox P. (eds) Advanced Dairy Chemistry. Springer, New York, NY.

Mourad, G., Bettach. G. and Samir, M. (2014). Composition and nutritional value of raw milk. Issues in Biological Sciences and Pharmaceutical Research. 2(10),115-122.

Nascimento, T. V. C., Júnior, W. L. G. A., Júnior, E. S. L., Menezes, D. R., Dias, F. S., and Costa M. M. (2017). Physical and chemical characteristics of milk from goats supplemented with different levels of total digestible nutrients in the dry period. Acta Scientiarum. 39(4)429-435. 
Rehman Z, Salariya A.M, Zafar, S.I. (2012). Effect of processing on available carbohydrate content and starch digestibility of kidney beans (Phaseolus vulgaris L.). Food Chemistry. 73:351-355.

Snedecro, G.W. and Cochran, G.W. (1967). Statistical Methods, 6th edition.The Iowa state University Press. Ames. Iowa, USA.

Shuiep ,E.S., El Zubeir, I.E. M., and Yousif, I.A. (2014). Compositional Quality of Camel Milk and Some Husbandry Practices Associated with Camel Milk Production in Two Production
Systems in Sudan. SUST Journal of Agricultural and Veterinary Sciences. 15 (2): 10-18.

Sood, A., Sood, R., Kumar, A., Kaur, G., Sidhu, C. (2016). Microbial quality analysis of milk and flavoured milk products from local vendors in Vellore. Electronic Journal of Biology, 12(1): 48-52.

Warsama, L.M., El Zubeir, I.E. M. (2015). Comparison of chemical composition of goat milk from farms and individual households in Khartoum State, Sudan, Management of land use systems for enhanced food security: conflicts, controversies and resolutions., Tropentag, September 16-18, 2015, Berlin, Germany. 